\title{
MECHANICAL STRENGTH OF STEMS IN AQUATIC MACROPHYTES
}

\author{
KATARZYNA BociąG ${ }^{1}$, AgNieszKa GAŁKA ${ }^{1}$, TYMON ŁAZAREwicZ ${ }^{2}$, JóZEF SZMEJA ${ }^{1}$ \\ ${ }^{1}$ University of Gdańsk, Department of Plant Ecology \\ Al. Legionów 9, 80-441 Gdańsk, Poland \\ e-mail: dokkb@univ.gda.pl \\ ${ }^{2}$ Gdańsk University of Technology, Department of Polymers Technology \\ Narutowicza 11/12, 80-952 Gdańsk, Poland
}

(Received: August 4, 2008. Accepted: July 2, 2009)

\begin{abstract}
In populations of submerged macrophytes, individuals are selected in terms of resistance to the effect of hydrodynamic forces. The aim of this study was to check whether individuals growing in river water are more tensile and bending resistant than plants occurring in places not exposed to flow stress. We determined the ultimate tensile strength of stems in four macrophyte species, Potamogeton natans, P. pectinatus, Batrachium fluitans and Chara fragilis, which occur in two environmental variants: in running (current velocity of $0.1-0.6 \mathrm{~m} / \mathrm{s}^{-1}$ ) and stagnant water. In addition, flexure of $P$. natans stems from both environmental variants was examined. What is more, the type and arrangement of strengthening structures in stems of the plants under study were determined.

Potamogeton natans stems are the most resistant to stretching $(15.6 \pm 4.7 \mathrm{~N})$, while stems of $P$. pectinatus $(3.3 \pm 1.0 \mathrm{~N})$ and Batrachium fluitans $(2.6 \pm 0.8 \mathrm{~N})$ are less resistant. Chara fragilis $(0.6 \pm 0.3 \mathrm{~N})$ has the least resistant stems. Batrachium, Chara and P. pectinatus are more resistant to stretching if they occur in a river current, whereas $P$. natans, in stagnant lake water. Ultimate bending moment of $P$. natans stems from lakes is also much greater than of stems from a river $\left(9.75 \cdot 10^{-3}-4.25 \cdot 10^{-3} \mathrm{Nm}\right.$ as compared to $\left.2.12 \cdot 10^{-3}-1.00 \cdot 10^{-3} \mathrm{Nm}\right)$.

The resistance of stems to breaking is directly proportional to the stem and thallus cross sectional areas. On the one hand, in all the studied Cormophyta species, the more resistant stems (in P. natans from stagnant water, in the others from running water) are thicker and characterised by a higher contribution of air spaces in the overall stem cross-section. On the other hand, the stems retain their species specific structure and have a similar proportion of strengthening elements.
\end{abstract}

KEY WORDS: aquatic macrophytes, water flow, mechanic properties, stretching, stem anatomy.

\section{INTRODUCTION}

Aquatic plants, like terrestrial ones, allocate part of their biomass to the formation of structures which anchor them in the substrate, strengthen them, give them solid shape and proper stiffness or elasticity.

On account of the fact that water is multiple times denser and more viscous than air, hydrodynamic pressure forces are about 800 times stronger than aerodynamic pressure. Thus, the mechanical effect of water is much stronger than that of air. It follows that adaptations to mechanical forces connected with water flow are of especial importance (Niklas 1992). In particular plants occurring in the littoral zones of seas and oceans are highly exposed to such forces, as they are under the effect of tides and strong wave activity. The effect of hydrodynamic forces on macroalgae dominant in this type of environment has been studied in detail (Koehl 1986; Gerard 1987; Wheeler 1988; Hurd 2000). Thallus thickness (Molloy and Bolton 1996; Kawa- mata 2001), thallus streamlining (Denny et al. 1985; Holbrook et al. 1991; Johnson and Koehl 1994; Utter and Denny 1996) and changes in biomass allocation (Wheeler 1988) are recognised as exemplary adaptations to the forces connected with water flow. Hydrodynamic forces affecting plants in rivers and lakes are most often weaker. Nevertheless, they sometimes serve as a factor limiting the occurrence of aquatic vegetation also in these environments (Szmeja 1994, 2006). The number of studies on the response of aquatic vegetation to water flow forces has increased recently (e.g. Coops and Velde van der 1996; Biehle et al. 1998; Shutten and Davy 2000).

Mechanical strength in vascular plants results not only from morphological structure (habitus) but also from the arrangement of tissues. Collenchyma and sclerenchyma are the crucial elements of mechanical support in higher plants. Collenchyma consists of living cells with cellulose walls containing pectin and is pliable, that is can be bent. Walls of these cells are unevenly thickened. According to 
Walker (1960) and Esau (1967), these cell wall thickenings are bigger in individuals exposed to mechanical forces than in those not exposed. This means that the discussed changes may be induced by environmental conditions. Thicker cell walls and the compact structure of collenchyma lead to increased stem strength. The second tissue type, sclerenchyma, consists of dead cells, sclereids and fibres. Walls of these cells are lignified and provide the plant with tensile and bending strength, which is essential for plants anchored in the substrate. The fibres are gathered in bundles of which the structure, number and arrangement determine the strength of stems (Moustafa et al. 1968; Zebrowski 1992).

It should be mentioned, though, that in a broader sense cell walls of all cells, irrespective of their type or function, are responsible for the plant's resistance to the effect of mechanical forces. The role of the so called initial stress and the fact that the plant's strength also depends on cell turgor have been more and more frequently emphasised (Hejnowicz 2002).

Undoubtedly, tensile and bending resistance are one of the important features of the plant life strategy in the aquatic environment. Accordingly, we assume that in the populations of submerged macrophytes individuals are selected in terms of resistance to the effect of hydrodynamic forces, which cause stretching, squashing, bending, buckling and twisting of their stems (or thalli). We intend to check whether plants growing in running water of a river have stems with higher tensile and bending resistance than those occurring in places not exposed to water flow. Moreover, we examined whether they differ in the number and arrangement of strengthening structures in their stems.

\section{MATERIAL AND METHODS}

\section{PLANT MATERIAL AND ENVIRONMENTAL CONDITIONS}

Four species of aquatic macrophytes, occurring in both stagnant and running water, were selected for the study: Potamogeton pectinatus L., P. natans L., Batrachium fluitans (Lam.) Wimm and Chara fragilis Desvaux. Lower stem parts (lower 0,1 $\mathrm{m}$ of the stem) of mature, equally aged individuals of Potamogeton and Batrachium, as well as orthotropous Chara thalli (lower $0.1 \mathrm{~m}$ of the above-ground part) were the subject of our study.

Individuals were collected from three rivers (Brda, Chocina and Zbrzyca) and three lakes (Ostrowite, Nawionek and Radolino) in NW Poland in July 2006 (each species from two sites, 50 individuals from each). A given species was represented by ca. 100 freshly collected stems or thalli, each $0.1 \mathrm{~m}$ in length. After harvest, the plants were kept in water at $10^{\circ} \mathrm{C}$ for maximum $12 \mathrm{~h}$. They were taken out of the water directly before measurements.

Two variants of aquatic environment were chosen for the experiments: (1) stagnant water without flow or wave activity (lakes or ox-bow lakes), and (2) running water (rivers). In each of these environmental variants, three water and three substrate samples were collected from the sites where the studied plants occurred (simultaneously with plant collection). The $\mathrm{pH}$, concentrations of total phosphorus (mg TP $\mathrm{dm}^{-3}$ ) and Kjeldahl nitrogen ( $\mathrm{mg} \mathrm{N}_{\text {Kjeld. }} \mathrm{dm}^{-3}$ ), and conductivity $\left(\mu \mathrm{S} \mathrm{cm} \mathrm{cm}^{-1}\right)$ were measured in the water, whereas hydration $(\%)$ and organic matter content $(\%)$ in the substrate. River current velocity $\left[\mathrm{m} \mathrm{s}^{-1}\right]$ was determined on the basis of the arithmetic mean from three measurements conducted on a one-off basis using the Nautilus C 2000 Sensor. Conductivity was measured by means of an LF 95 meter equipped with a Tetra Con 96 cell, pH was determined using a 320 SET 1 pH-meter, and TP concentration by the molybdate colorimetric method with ascorbic acid, for $\lambda=690 \mathrm{~nm}$. Kjeldahl nitrogen was determined by converting organic nitrogen to ammonium sulphate, for $\lambda=$ $690 \mathrm{~nm}$ (Hermanowicz et al. 1999; Eaton et al. 2005).

\section{ASSESSMENT OF MECHANICAL PROPERTIES}

The study of mechanical properties of Potamogeton pectinatus, $P$. natans, Batrachium fluitans and Chara fragilis, which involved stretching stems or thalli, was performed on a testing machine Z020 manufactured by Zwick/Roell, a popular apparatus for tensile tests of materials. The plant samples were strained at a constant speed of $1.67 * 10^{-3} \mathrm{~m} \mathrm{~s}^{-1}$ $(100 \mathrm{~mm} / \mathrm{min})$ at an ambient temperature. The force $F$ was measured versus tensile strain (relative elongation) $\varepsilon$

$$
\varepsilon=\frac{l-l_{0}}{l_{0}},
$$

where:

$l$ - the length of the stretched sample

$l_{0}-$ the initial length

Each sample was placed in gripping jaws set $l_{0}=0.05 \mathrm{~m}$ apart.

These measurements resulted in force-strain diagrams. The maximum values of forces $\left(R_{m}\right)$ acting on the samples (ultimate tensile forces), the exceeding of which caused the samples to break, were read from the plots. After averaging and assessment by statistical methods, the measurement results became the criterion for evaluation of the tensile strength. Only the maximum forces exerted on stems or thalli (samples) were analysed. However, their stresses were not considered, as they are regarded as anisotropic materials in the mechanical sense.

Tensile strength evaluation was supplemented by three point flexural tests of Potamogeton natans stems. The stems were placed on supports (Fig. 1). Distance between the supports $l$ was $0.05 \mathrm{~m}$. The stems were bent with a knife $l / 2$ distant from each support, which moved with a constant speed of $0.167 * 10^{-3} \mathrm{~m} \mathrm{~s}^{-1}(10 \mathrm{~mm} / \mathrm{min})$, and force $F$ transverse to the axis of the stem and acting on the knife was recorded. Next the maximum forces transmitted during bending were determined. The ultimate bending moment $M_{g \max }[\mathrm{Nm}]$ was calculated from the relation

$$
M_{g \max }=\frac{F l}{4},
$$

where $F$ - force exerted on a sample [N]. Mean values of bending moments are the criterion for the evaluation of bending strength of stems. Tensile and three point bending tests were performed on Zwick/Roell Z020 testing machine at ambient temperature. 


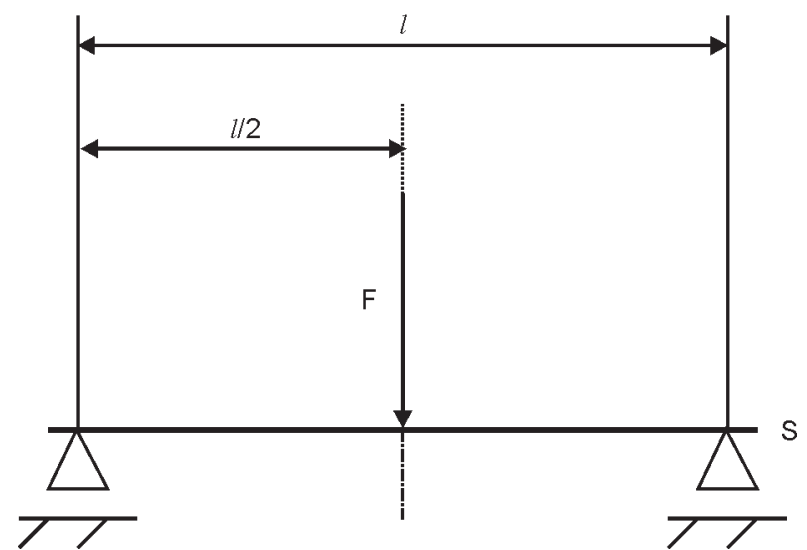

Fig. 1. Schematic side view of three point bending test geometry.

Explanations: F - force; 1 - length; s - stem

\section{Anatomical analysis}

In order to investigate the possible differences in stem anatomy of the studied species from both selected environments, two cross sections of the lower part of the internode (10 $\mathrm{cm}$ above ground) were made in each case. Preparations were made by the paraffin method (staining with eosine, safranine and fast green) and the hand-section method (staining with safranine) according to Gerlach (1972) and Braune et al. (1975). The microtome sections were 10 $\mu \mathrm{m}$ thick and hand sections 20-30 $\mu \mathrm{m}$. Photographic documentation of pictures obtained from a NIKON Eclipse E800 light microscope was collected and later analysed by means of the computer program Corel 9.0. We studied the distribution pattern and contribution of strengthening structures in the cross sectional area, especially that of fibres and sclerenchyma cells, as well as endodermis cells, vascular bundles and systems of aerenchymatic air spaces. The area of stem cross sections was also determined.

The significance of differences between arithmetic means of stem mechanical properties was tested using the Kruskal-Wallis test for $\mathrm{p}<0.001$ and the U Mann-Whitney test for $\mathrm{p}<0.05$.

\section{RESULTS}

\section{Environmental conditions}

The plants grew in stagnant water without flow (2 lakes and 1 ox-bow lake) and in three lowland well-preserved rivers with a current velocity of $0.2-0.4 \mathrm{~m} \mathrm{~s}^{-1}$ (all-year-round flow, variable velocity dependent on water level in the river). In both environmental variants the plants occurred at a depth of around $1.0 \mathrm{~m}$, were dominant in the vegetation structure and occupied a similar type of substrate. Hence we could assume in advance that depth, substrate and illumination were not crucial factors differentiating both environmental options. What is more, the occurrence of plants in single-species aggregations, where they were dominant, excludes the effect of interspecific competition on the mechanical strength of stems.

In stagnant water the variation range of water features is similar to the range observed in river currents (Table 1). In both environmental variants the substrate is mineral (in the lakes sandy, in the rivers sandy and gravel) and contains a small (several per cent) fraction of organic matter (Table 1). The variation ranges of water (except for $\mathrm{N}_{\text {Kjeld. }}$ ) and substrate features are fairly narrow and coincide to a large extent in both environments. We assume, thus, that chemical water and substrate properties are not an important cause of differences in mechanical strength of aquatic macrophyte stems.

\section{Mechanical strength}

The plants differ in terms of resistance to hydrodynamic forces (Fig. 2). The highest ultimate tensile forces of stretched samples were observed for Potamogeton natans (15.6 $\pm 4.7 \mathrm{~N}$; data for $\mathrm{n}=55$ shoots), while for $P$. pectinatus $(3.3 \pm 1.0 \mathrm{~N} ; \mathrm{n}=52)$ and Batrachium fluitans $(2.6 \pm 0.8$ $\mathrm{N} ; \mathrm{n}=55$ ) lower values were observed. The lowest values of ultimate tensile strength were measured for Chara fragilis $(0.6 \pm 0.3 \mathrm{~N} ; \mathrm{n}=56)$. It should be mentioned that, contrary to $P$. natans, which is the strongest in stagnant lake water, Batrachium, Chara and $P$. pectinatus are stronger when they occur in a river current. The $P$. natans stem growing in a lake breaks under the conditions of a force of 15.6 $\pm 4.7 \mathrm{~N}$, while in the case of a river this happens when the exerted force is twice as low $(9.3 \pm 2.2 \mathrm{~N} ; \mathrm{n}=53)$.

The examples of force-strain plots for investigated species from stagnant (A) and running water (B) were collected in Figure 3.

$P$. natans stems from stagnant water were more resistant to bending, too. Ultimate bending moments of these stems are much greater than those of the samples taken from a river $\left(9.75 \cdot 10^{-3}-4.25 \cdot 10^{-3} \mathrm{Nm}\right.$ as compared to $2.12 \cdot 10^{-3}$ $1,00 \cdot 10^{-3} \mathrm{Nm}$; Fig. 4). It is worth mentioning that differences in stem strength of all the studied plant species calculated for both environments are statistically significant $(\mathrm{p}<0.05)$.

\section{Anatomical structure}

Potamogeton natans stems from lakes are the most tensile-resistant (Fig. 4) and have the biggest cross sectional

TABLE 1. Comparison of the aquatic environment features without and with flow.

The table presents the feature range (minimum-maximum) and arithmetic mean \pm standard deviation (in brackets) for $\mathrm{pH}-\mathrm{median}$.

\begin{tabular}{|c|c|c|}
\hline Environmental option & Without flow & With flow \\
\hline Flow speed $\left[\mathrm{m} \mathrm{s}^{-1}\right]$ & 0 & $0.2-0.4(0.3 \pm 0.1)$ \\
\hline $\mathrm{pH}_{\mathrm{w}}$ & $7.4-8.3(8.08)$ & $7.4-7.9(7.61)$ \\
\hline $\mathrm{TP}_{\mathrm{w}}\left[\mathrm{mg} \mathrm{dm}^{-3}\right]$ & $0.1-0.4(0.2 \pm 0.1)$ & $0.02-0.8(0.35 \pm 0.29)$ \\
\hline $\mathrm{N}_{\text {Kjeld.w }}\left[\mathrm{mg} \mathrm{dm}^{-3}\right]$ & $0.9-1.9(1.2 \pm 0.3)$ & $1.2-2.4(1.8 \pm 0.4)$ \\
\hline Water conductivity $\left[\mu \mathrm{sm}^{-1}\right]$ & $48.5-311(172.5 \pm 84.7)$ & $128.5-300(216.2 \pm 49.5)$ \\
\hline Organic matter in sediment [\%] & $0.2-3.4(1.5 \pm 0.9)$ & $0.2-15.5(2.7 \pm 4.5)$ \\
\hline Sediment hydration [\%] & $16.3-70.9(30.4 \pm 13.6)$ & $7.8-56(20.8 \pm 14.8)$ \\
\hline
\end{tabular}



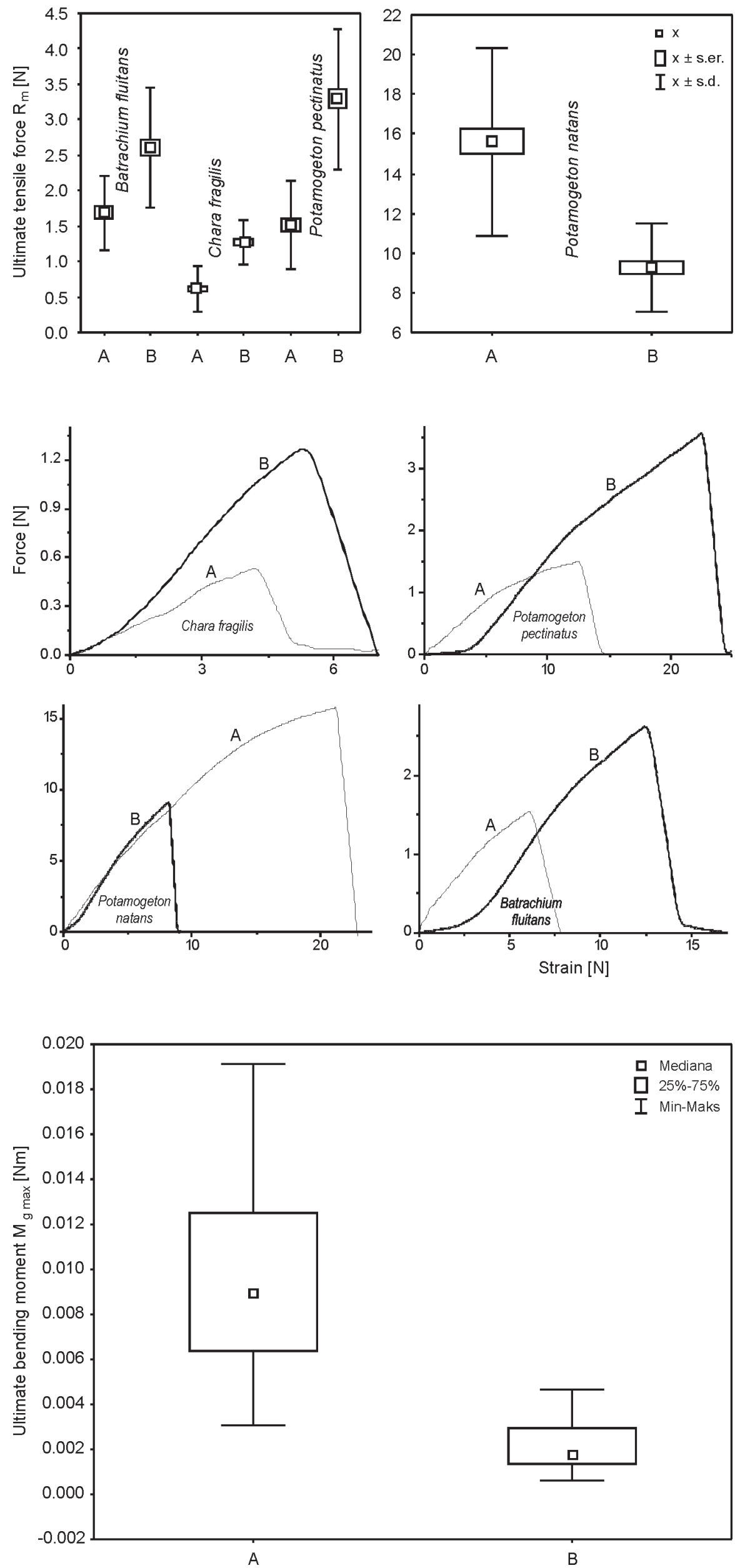

Fig. 2. Values of the ultimate tensile force breaking samples of Batrachium fluitans, Chara fragilis, Potamogeton pectinatus and $P$. natans from lake (A) and river (B).

Fig. 3. The dependence of tensile force on strain for Batrachium fluitans, Chara fragilis, Potamogeton pectinatus and $P$. natans from lake (A) and river (B).

Fig. 4. Values of the ultimate bending moment $M_{g \text { max }}[\mathrm{Nm}]$ of stems form stagnant (A) and running (B) water. 
A

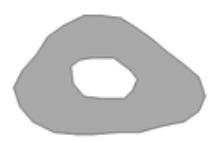

Batrachium fluitans

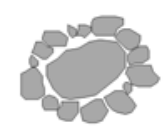

Chara fragilis

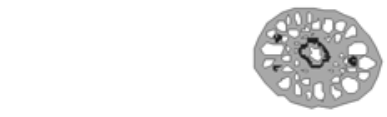

Potamogeton pectinatus

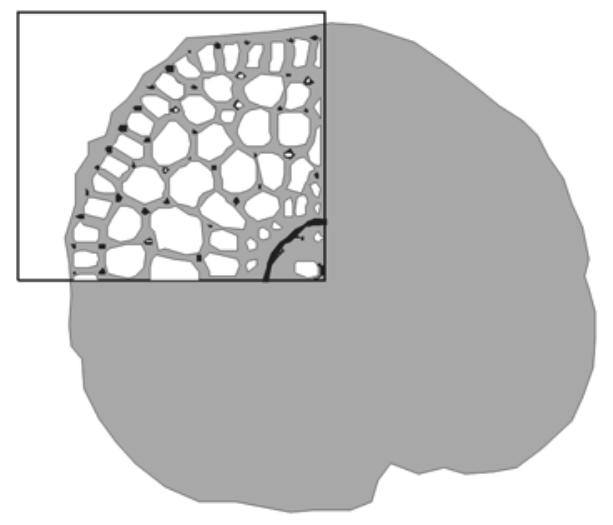

Potamogeton natans

area (Fig. 5). The stems of this species from rivers have a much smaller cross sectional area. In comparison with this species, the cross sectional areas of $P$. pectinatus, $B a$ trachium fluitans and Chara fragilis stems are several times smaller (Fig. 5). The stem resistance to tensile force is directly proportional to the cross sectional area of a stem or thallus (Fig. 6).

In the cross section of the studied Cormophyta stems the proportion of strengthening tissues does not exceed $4 \%$.

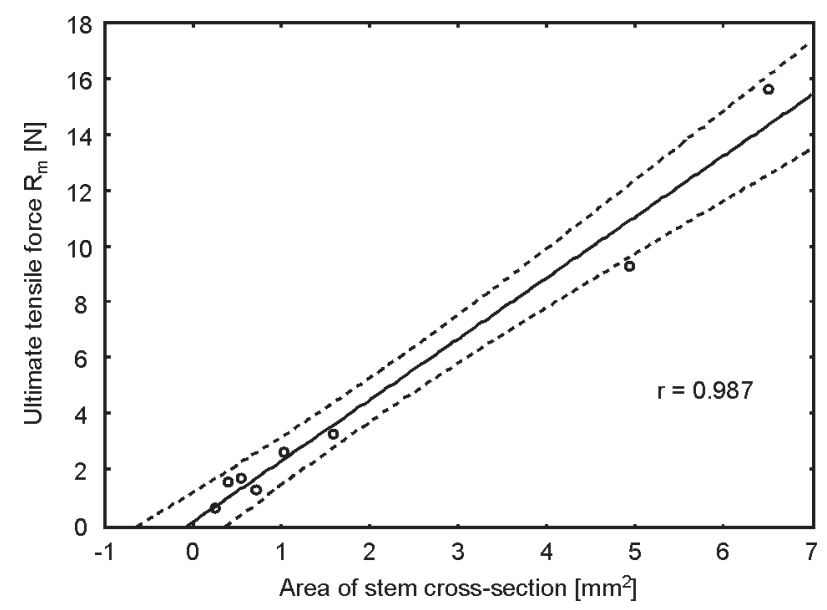

Fig. 6. Relation between ultimate tensile force and cross sectional area of an aquatic plant stem.
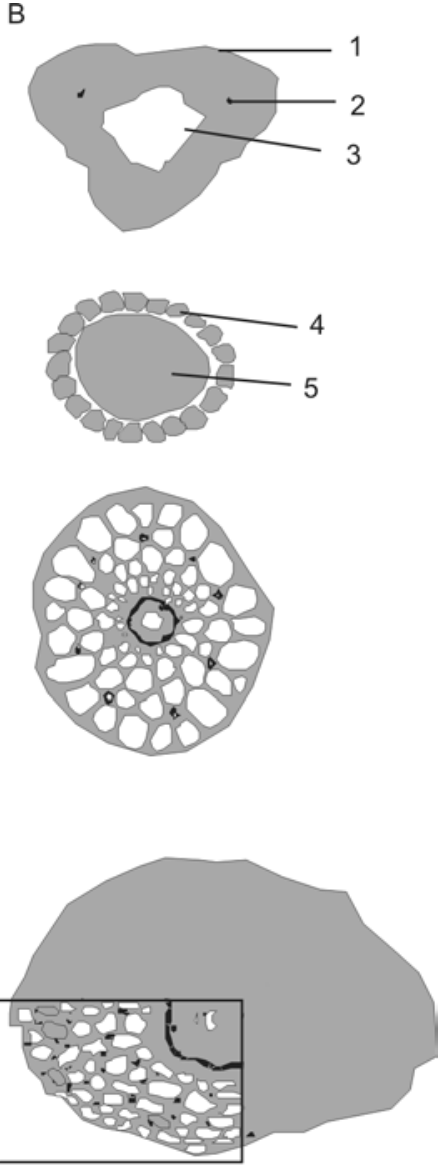

$1 \mathrm{~mm}$
Fig. 5. Schematic representation of cross sections of Batrachium fluitans, Potamogeton natans and $P$. pectinatus stems and Chara fragilis thallus in stagnant (A) and running (B) water.

Explanations: 1 - epidermis; 2 - parenchyma; 3 - air spaces; 4 - cortical cells; 5 - central cell.

Sclerenchyma fibres in the primary cortex and pith, and in Potamogeton also the ring of endodermis cells, constitute the strengthening elements. Air spaces represent a considerable part of the stem cross section $(32-49.5 \%$ of the cross sectional area in Potamogeton and 13.3-17.6\% in Batrachium). Apart from their cross sectional area, Potamogeton and Batrachium stems differ in structure, tissue arrangement and their relative proportion in the overall stem cross section (Fig. 5). Potamogeton stems have a concentric arrangement of strengthening elements, which resembles a double-layer cylinder. The continuous ring of well-developed tertiary U-endodermis is the inner layer, whereas the sclerenchyma fibres in the peripheral part of the primary cortex constitute the discontinuous outer layer. Between these two rings there are air spaces whose "walls" are strengthened with thin sclerenchyma fibres. The diagram of a Batrachium fluitans stem resembles a thick-walled pipe with a triangular cross section with few strengthening elements (Fig. 5). There is no aerenchyma or endodermis in it, and the central part is taken up by an air space. A few sclerenchyma cells occur only in stems from running water. It should be considered on the basis of mechanics to what extent the differences in the stem strength of the studied Cormophyta, apart from being connected with the cross sectional area, result from a slightly different structure.

The main thallus axis of Chara fragilis is composed of an elongated central cell and surrounding cortical cells (Fig. 5). 
Cell walls and calcium carbonate encrustation strengthen the thallus. Its tensile strength probably depends on the thickness of its main axis, cell arrangement, their size and turgor.

The more resistant stems in Cormophyta (from stagnant water in $P$. natans, from running water in the others) are thicker and characterised by a greater contribution of air spaces in the overall stem cross-section. Irrespective of the environmental option, however, stems have an immutable species-specific structure and a similar proportion of strengthening elements (Fig. 5).

\section{DISCUSSION}

Having compared the values of the analysed forces, we concluded that the tensile and bending resistance of stems depends not only on species features, but also properties acquired by individuals in the aquatic environment. Biehle et al. (1998), who studied various Fontinalis antipyretica populations, and Boeger and Poulson (2003), who examined Veronica anagallis-aquatica, came to similar conclusions. One cannot tell if the observed differences are adaptations or plastic responses to environmental conditions which have not been genetically preserved. It seems, however, that tensile and bending resistance of stems is an element of life strategy, as an adaptation to water flow, and depends, for example, on the anatomical and morphological plasticity of individuals in populations. Wernberg et al. (2003) and Wernberg and Thomsen (2005) expressed a similar opinion on macroalgae.

Chara fragilis (Fig. 3), which generally occurs in stagnant waters with very low wave activity, is not a stretching-resistant macrophyte. Its thallus is encrusted with calcium carbonate and consequently not very flexible, and its main axis is much thinner than the stems of the studied Cormopthyta. Individuals from a river may be a little more stretching-resistant than those from a lake, but compared with Cormophyta, they are much more delicate.

One should bear in mind that the actual resistance of plants to water flow results not only from the susceptibility of stems. It should be considered in the context of morphological structure and anatomy of the whole plant, as well as shape and structure of its aggregations and the spatial population distribution. It is well known that hydrodynamic forces acting on individuals from dense aggregations are several times weaker due to the flow reduction inside the aggregations (Sand-Jensen and Mebus 1996; Sand-Jensen and Pedersen 1999). On the other hand, forces exerted on individuals from the aggregation margin to a large extent depend on its shape, rather than only on the features of individuals (Velasco et al. 2003). Accordingly, Chara fragilis can probably occur in waters with a considerable flow, provided that it grows in very dense aggregations streamlined in shape.

Cormophyta are characterised by a higher stretching resistance than $C h$. fragilis. They have thicker stems of which the strength depends on their anatomy, especially the presence of strengthening tissues and air spaces. It is worth noting that forces breaking Cormophyta stems are stronger than those observed in a moss species Fontinalis antipyretica, of which the anatomy is much more simple (see Biehle et al. 1998).
The Cormophyta under study have various stem structures, but they do not change with the environmental variant. It should be emphasized that the proportion of the strengthening tissue in stem cross sections is small $(<5 \%)$, which, according to Brewer and Parker (1990), may indicate that they assume the "flexible and stretchy" strategy, rather than, "stiff and strong" one. Nevertheless, the relative proportion of air spaces in the overall stem cross section, especially in Potamogeton stems, is considerable. Such a stem structure is considered to be optimal, as it minimizes the biomass input and has a beneficial influence on strength (Niklas 1992; Hejnowicz 2002).

There is a big difference in tensile strength between $P_{O}$ tamogeton natans and P. pectinatus or Batrachium fluitans. Even though $P$. pectinatus and Batrachium fluitans more often occur in rivers with a fairly fast flow, the tensile strength of Potamogeton natans stems is much higher. This could probably be due to the presence of floating leaves, which, offering resistance to the water current, may contribute to the plant's mechanical strength. $P$. pectinatus and $B$. circinatum have no floating leaves. When $P$. pectinatus and $B$. circinatum occur in running water, they adopt an elongated habitus, especially $P$. pectinatus, and form dense aggregations inside which hydrodynamic forces are dampened. Thanks to the changed habitus and dense aggregations, stems of these plants are less susceptible to breaking than individuals of $P$. natans.

We confirmed the hypothesis that stems of river plants are of higher tensile strength than plants from stagnant water. Potamogeton natans, whose individuals from a lake are more resistant to stretching and bending than the ones from a river, is the exception to this rule. The plant usually occurs in stagnant or slowly running waters, and only rarely in smaller numbers in fast flowing rivers. The smaller stem diameter in river individuals may be a consequence of water flow stress. A similar response was observed in amphibious Veronica anagallis-aquatica, in a river, by Boeger and Poulson (2003). The fact that macrophytes respond to water flow by forming floating leaves makes them similar to amphibious, rather than underwater plants.

In the light of the trade-off conception, the habit and anatomy of plants in running water environment are an expression of a peculiar compromise. The life strategies of such plants are worth considering in a wider context suggested by Madsen and Sřndergaard (1983), Jenkins and Proctor (1985), Jackelman and Bolton (1990), Blanchette (1997), Riis and Biggs (2001) and Blanchette et al. (2002) for example, taking account of their gas exchange, capacity for photosynthesis, productivity and growth rate.

\section{ACKNOWLEDGEMENTS}

The authors would like to thank Professor Józef Haponiuk for his help with the organization of mechanical experiments, Jolanta Romaniuk, MSc, for the microscopic preparations of stem cross sections and their photographic documentation, and Emilia Pokojska for translating this text into English. The studies were financed from funds allocated for science as a research project (2 P04G 00127 ). 


\section{LITERATURE CITED}

BIEHLE G., SPECK T., SPATZ H.-C. 1998. Hydrodynamics and biomechanics of submerged water moss Fontinalis antipyreti$c a-a$ comparison of specimens from habitats with different flow velocities. Bot. Acta 111: 42-50.

BLANCHETTE C.A. 1997. Size and survival of inertidal plants in response to wave action - a case study with Fucus gardneri. Ecology 78: 1563-1578.

BLANCHETTE C.A., MINER B.G., GAINES S.D. 2002. Geographic variability in form, size and survival of Egregia menziesii around point conception. California. Mar. Ecol. Prog. Ser. 239: 69-82.

BOEGER M.R., POULSON M.E. 2003. Morphological adaptations and photosynthetic rates of amphibious Veronica anagalis-aquatica L. under different flow regimes. Aquat. Bot. 75:123-135.

BRAUNE W., LEMAN A., TAUBERT H. 1975. Praktikum $\mathrm{Z}$ anatomii roślin. PWN, Warszawa. (in Polish)

BREWER C., PARKER M. 1990. Adaptations of macrophytes to life in moving water: upslope limits and mechanical properties of stems. Hydrobiol. 194:133-142.

COOPS H., VELDE VAN DER G. 1996. Effects of waves on helopyte stands: mechanical characteristics of stems of Phragmites australis and Scirpus lacustris. Aquat. Bot. 53: 175-185.

DENNY M.W., DANIEL T.L., KOEHLER M.A.R. 1985. Mechanical limits to size in wave-swept organisms. Ecological Monographs 55: 69-102.

EATON A.D., CLESCERI L.S., RICE E.W., GREENBERG A.E. 2005. Standard methods for the examination of water and wastewater. Am. Publ. Health Ass., Washington.

ESAU K. 1967. Plant anatomy. Jon Wiley \& Sons, Inc., New York.

GERARD V.A. 1987. Hydrodynamic streamlining of laminaria saccharina Lamour in response to mechanical stress. J.Exp.Mar.Biol.Ecol. 107: 237-244.

GERLACH D. 1972. Zarys mikrotechniki botanicznej. PWRiL, Poznań. (in Polish)

HEJNOWICZ Z. 2002. Anatomia i histogeneza roślin naczyniowych. Organy wegetatywne. Wyd. Naukowe PWN, Warszawa. (in Polish)

HERMANOWICZ W., DOŻAŃSKA W., DOJLIDO J., KOZIOROWSKI B. 1999. Physico-chemical analysis of water and sewage. Arkady, Warszawa (in Polish).

HOLBROOK N.M., DENNY M.W., KOEHL M.A.R. 1991. Intertidal "trees": consequences of aggregation on the mechanical and photosynthetic properties of sea-palm Postelsia palmaeformis. J. Exp. Mar. Biol. Ecol. 146: 39-67.

HURD C.L. 2000. Water motion, marine macroalgal physiology, and production. J. Phycol. 36: 453-472.

JACKELMAN J.J., BOLTON J.J. 1990. Form variation and productivity of an intertidal foliose Gigartina species (Rhodophyta) in relation to wave exposure. Hydrobiologia 204/205: 57-64.

JENKINS J.T., PROCTOR M.C.F. 1985. Water velocity, growthform and diffusion resistances to photosynthetic $\mathrm{Co} 2$ uptake in aquatic bryophytes. Plant Cell. Environ. 8: 317-323.

JOHNSON A.S., KOEHL M.A.R. 1994. Maintenance of dynamic strain similarity and environmental stress factor in different flow habitats: thallus allometry and material properties of a giant kelp. J. Exp. Biol. 195: 381-410.
KAWAMATA S. 2001. Adaptive mechanical tolerance and dislodgment velocity of the kelp Laminaria japonica in wave-induced water motion. Mar. Ecol. Progr. Ser. 211:89-104.

KOEHL M.A.R. 1986. Seaweds in moving water: form and mechanical function, pp. 603-634. In: T.J. Givinish (ed.), On the economy of plant formand function. Cambridge University Press, Cambridge.

MADSEN T.V., SRKNDERGAARD M. 1983. The effects of current velocity on the photosynthesis of Callitriche stagnalis Scop. Aquat. Bot. 15: 187-193.

MOLLOY F.J., BOLTON J.J. 1996. The effect of wave exposure and depth on the morphology of inshore populations of the Namibian kelp Laminaria schinzii Foslie. Bot. Mar. 39: 525-531.

MOUSTAFA S.M.A., STOUT B.A., BRADLEY W.A. 1968. Elastic and inelastic stability of a biological structure. J. Agric. Eng. Res. 13: 64-82.

NIKLAS K.J. 1992. Plant biomechanics. An engineering approach to plant form and function. Univ. Chicago Press, Chicago, London, $607 \mathrm{pp}$.

RIIS T., BIGGS B.J.F. 2001. Distribution of macrophytes in New Zealand streams and lakes in relation to disturbance frequency and resource supply - a synthesis and conceptual model. New Zealand J. Marine Freshwater Res. 35: 255-267.

SAND-JENSEN K., MEBUS J.R. 1996. Fine-scale patterns of water velocity within macrophyte patches in streams. Oikos 76: $169-180$.

SAND-JENSEN K., PEDERSEN O. 1999. Velocity gradients and turbulence around macrophyte stands in streams. Freshwater Biol. 42: 315-328.

SCHUTTEN J., DAVY A.J. 2000. Predicting the hydraulic forces on submerged macrophytes from current velocity, biomass and morphology. Oecologia 123: 445-452.

SZMEJA J. 1994. Effect of disturbances and interspecific competition in isoetid populations. Aquatic Bot. 48: 225-238.

SZMEJA J. 2006. Przewodnik do badań roślinności wodnej. Wyd. UG, Gdańsk. (in Polish)

UTTER B.D., DENNY M.W. 1996. Wave-induced forces on the giant kelp Macrocystis pyrifera (Agardh): field test of a computational module. J. Exp. Biol. 199: 2645-2654.

VELASCO D., BATEMAN A., REDONDO J.M., DEMEDINA V. 2003. An open channel flow experimental and theoretical study of resistance and turbulent characterization over flexible vegetated linings. Flow, Turbulence and Combusion 70: 69-88.

WALKER W.S. 1960. The effect of mechanical stimulation and etiolation on the collenchyma of Datura stramonium. Am. J. Bot. 47: 717-724.

WERNBERG T., COLEMAN M., FAIRHEAD A., MILLER S., THOMSEN M. 2003. Morphology of Eclonia radiata along its geographic distribution in south-western Australia and Australasia. Mar. Biol. 143: 47-55.

WERNBERG T., THOMSEN M.S. 2005. The effects of wave exposure on the morphology of Eclonia radiata. Aquat. Bot. 83: 61-70.

WHEELER W.N. 1988. Algal productivity and hydrodynamics a synthesis. Prog. Phycol. Res. 6: 23-58.

ZEBROWSKI J. 1992. Complementary patterns of stiffness in stem and leaf sheaths of Triticale. Measurements of ultrasound velocity. Planta 187: 301-305. 